\title{
Short and long term prognosis of acute myocardial infarction since introduction of thrombolysis
}

\author{
Robert Stevenson, Kulasegaram Ranjadayalan, Paul Wilkinson, Robin Roberts, Adam D Timmis
}

Abstract

Objective-To record prognosis and determinants of outcome in patients with acute myocardial infarction since thrombolysis was introduced.

Design-Observational study.

Setting-London district general hospital.

Patients-608 consecutive patients admitted to the coronary care unit with acute myocardial infarction between 1 January 1988 and 31 December 1991.

Main outcome measure-All cause mortality, non-fatal ischaemic events (myocardial infarction, unstable angina), and revascularisation.

Results-Of the 608 patients, $89(14.6 \%)$ died in hospital. 596 patients were followed up after discharge from hospital. Mortality $(95 \%$ confidence interval) at 30 days, one year, and three years was $16.0 \%(13 \cdot 4 \%$ to $19 \cdot 2 \%), 21 \cdot 7 \%(18 \cdot 6 \%$ to $25 \cdot 2 \%)$, and $29 \cdot 4 \%(25 \cdot 3 \%$ to $33 \cdot 9 \%)$ respectively. Event free survival (survival without a non-fatal ischaemic event) was $80 \cdot 4 \%(77 \cdot 0 \%$ to $83.4 \%)$ at 30 days, $66.8 \%$ $(62 \cdot 8 \%$ to $70 \cdot 5 \%)$ at one year, and $56 \cdot 1 \%(51 \cdot 3 \%$ to $60.6 \%$ ) at three years. Survival in patients treated with thrombolysis was considerably higher than in those not given thrombolysis (three year survival: $76 \cdot 7 \% v 54 \cdot 3 \%$ ), although the incidence of non-fatal ischaemic events was the same in the two groups. Multivariate determinants of six month survival were left ventricular failure, treatment with thrombolysis and aspirin, smoking history, bundle branch block, and age. For patients who survived six months, age was the only factor related to long term survival.

Conclusions-Although patients treated by thrombolysis had a relatively good prognosis, long term mortality and the incidence of non-fatal recurrent ischaemic events remained high. Effective strategies for the identification and treatment of high risk patients need to be reassessed.

\section{Introduction}

Observational studies of patients with acute myocardial infarction have shown a steady improvement in short term prognosis during the past 30 years and have also documented the main clinical determinants of outcome. ${ }^{12}$ All these studies, however, were conducted before thrombolysis was introduced. Controlled clinical trials have shown conclusively that thrombolysis and aspirin reduce mortality in the generally low risk patients who have fulfilled selection criteria, but little information is available on the prognostic impact of thrombolysis in routine clinical practice. We examined short and long term survival in a large series of consecutive patients with acute myocardial infarction admitted to the coronary care unit of a district hospital. Unlike in previous studies of this type, thrombolysis and aspirin were used throughout the study period.

\section{Subjects and methods}

The study group comprised all patients admitted to the coronary care unit of Newham General Hospital with acute myocardial infarction during 1 January 1988 to 31 December 1991. During this period there were $633 \mathrm{admissions,} \mathrm{including} 25$ patients who were admitted twice. Since survival was taken from the first admission only, the study group consisted of 608 patients. During the study period there were a further 924 admissions to the coronary care unit including patients with unstable angina, cardiac arrhythmias, and non-cardiac chest pain. Newham General Hospital is the only acute general hospital in the Newham Borough of east London and serves a population of about 220000 . It was hospital policy to admit all patients with suspected acute myocardial infarction to the coronary care unit regardless of age. The study was started at the time thrombolytic therapy had become established as part of routine management of patients with acute myocardial infarction. The diagnosis of myocardial infarction was based on any two of the following three criteria: typical chest pain, ST elevation $\geqslant 0.1 \mathrm{mV}$ in at least one standard or two precordial leads, rise in serum creatine kinase concentration to greater than twice the normal laboratory value (400 IU/l). Thrombolysis was recommended for any patient with suspected myocardial infarction who presented within 24 hours of the onset of continuous chest pain and who had ST elevation greater than $0.1 \mathrm{mV}$ in at least one standard or two adjacent precordial leads. Contraindications to thrombolysis were recent history of peptic ulceration with active symptoms, recent stroke or surgery (previous four to six weeks), prolonged cardiopulmonary resuscitation, and bleeding diathesis. Left or right bundle branch block was not a contraindication to thrombolysis if other crtieria for acute infarction were fulfilled. Seventy one patients presented with or developed left $(n=24)$ or right $(n=47)$ bundle branch block during the course of admission. Of these, 14 and 30 patients, respectively, received thrombolysis. The decision whether to prescribe or withhold thrombolysis was left to the discretion of the admitting doctor. All drugs, including aspirin, were prescribed as indicated by the admitting doctor (table I).

Baseline clinical data were collected prospectively and stored electronically. The following information was recorded: clinical history, examination findings, electrocardiographic data, cardiac enzyme concentrations, chest radiography findings, and details of treatment. The diagnosis of left ventricular failure required there to be symptoms of breathlessness accompanied by basal crepitations or a third heart sound, or both, and treatment with diuretics. Diabetes was recorded if the patient required insulin, oral hypoglycaemic drugs, or dietary restriction. Data relating to smoking habits were obtained on admission. Patients were divided into three groups: non-smokers (those who had never
Correspondence to: Dr Stevenson.

$B M \mp 1993 ; 307: 349-53$ 
TABLE I-Details of drug treatment at admission and at hospital discharge

\begin{tabular}{|c|c|c|}
\hline & $\begin{array}{c}\text { No (\%) of } \\
\text { patients } \\
\text { at } \\
\text { admission } \\
(n=514)\end{array}$ & $\begin{array}{l}\text { No }(\%) \text { of } \\
\text { patients } \\
\text { at } \\
\text { discharge } \\
(n=493)\end{array}$ \\
\hline Aspirin & $61(12)$ & $423(86)$ \\
\hline$\beta$ blockers & $87(17)$ & $185(38)$ \\
\hline Diuretics & $82(16)$ & $127(26)$ \\
\hline Nitrates & $112(22)$ & NA \\
\hline Calcium & & \\
\hline antagonists & $69(13)$ & NA \\
\hline
\end{tabular}

$\mathrm{NA}=$ not available.

TABLE II-Baseline

characteristics of study population

\begin{tabular}{lc}
\hline & $\begin{array}{c}\text { No (\%) of } \\
\text { patients } \\
(\mathrm{n}=608)\end{array}$ \\
\hline Age (years): & \\
$>70$ & $159(26 \cdot 2)$ \\
$60-69$ & $185(30 \cdot 4)$ \\
$50-59$ & $169(27 \cdot 8)$ \\
$<50$ & $95(15 \cdot 6)$ \\
Male & $447(73 \cdot 5)$ \\
Ethnic group: & \\
White & $468(77 \cdot 0)$ \\
Asian & $128(21 \cdot 1)$ \\
Afro Caribbean & $12(2 \cdot 0)$ \\
Treatment: & \\
Aspirin plus & \\
$\quad$ thrombolysis & $387(63 \cdot 7)$ \\
Thrombolysis only & $54(8 \cdot 9)$ \\
Aspirin only & $103(16 \cdot 9)$ \\
Neither & $64(10 \cdot 5)$ \\
Infarct site: & \\
Anterior & $300(49 \cdot 3)$ \\
Inferior & $305(50 \cdot 2)$ \\
Indeterminate & $3(0 \cdot 5)$ \\
Q wave: & \\
Q & $472(77 \cdot 6)$ \\
Non-Q & $136(22 \cdot 4)$ \\
Diabetes: & $118(19 \cdot 4)$ \\
History of myocardial & \\
infarction: & $152(25 \cdot 0)$ \\
Smoking history: & \\
Current smoker & $350(57 \cdot 6)$ \\
Former smoker & $98(16 \cdot 1)$ \\
Never smoked & $160(26 \cdot 3)$ \\
\hline & \\
\hline &
\end{tabular}

smoked), former smokers (those who had stopped smoking over a month before the index infarction), and current smokers. The results of blood cholesterol concentrations were not recorded on the database.

In all, 608 patients survived until discharge from hospital, although information regarding non-fatal recurrent ischaemic events or revascularisation, or both, could not be verified in four cases. Follow up after discharge was continued until June 1992 and data were obtained on $596(98 \%)$ patients. Ischaemic events during the first admission to hospital were recorded prospectively. Long term follow up was obtained initially by questionnaire and telephone interview, and details of readmissions to hospital were then obtained by reviewing the case records of the relevant hospital. Details of deaths occurring out of hospital were obtained from the general practitioner. The following end points were recorded: death, non-fatal ischaemic events (myocardial infarction, unstable angina), coronary artery bypass surgery, and coronary angioplasty. The diagnostic criteria for reinfarction were the same as for entry into the study, and unstable angina was defined as prolonged cardiac chest pain associated with acute changes on electrocardiography requiring urgent admission to the coronary care unit.

\section{STATISTICAL ANALYSIS}

Survival curves were generated by the Kaplan-Meier method $^{3}$ and survival probabilities expressed as percentages with $95 \%$ confidence intervals. Subgroups were compared by the log rank test. For the 25 patients who were admitted twice during the study period survival was taken from the first admission only; their second infarction was analysed as one of the main end points. Multivariate predictors of survival were based on a proportional hazards model, ${ }^{4}$ with improvements in model fit based on the likelihood ratio statistic. The proportionality assumption central to the Cox model was examined by inspecting log cumulative hazard curves for non-parallelism and by testing for improvements in model fit with log time interaction terms.

\section{Results}

During the study period the use of thrombolytic therapy rose from $54 \%$ of cases in 1988 to $80 \%$ by 1991 , and the use of aspirin increased from $46 \%$ to $93 \%$.

Acute myocardial infarction was confirmed by analysis of cardiac enzyme concentrations in 473 (78\%) patients, all of whom developed peak creatine kinase concentrations above $400 \mathrm{IU} / \mathrm{l}$. Of the remaining 135 patients, 46 died before a rise in enzyme concentrations could be detected and 53 developed diagnostic $Q$ waves. Thus 36 patients had non- $Q$ wave infarction without a documented rise in cardiac enzymes, but all of these presented with prolonged cardiac chest pain and unequivocal regional ST elevation and all received thrombolysis.
TABLE III-Event free survival analysis for death from all causes; death from all causes and recurrent ischaemic events; and death from all causes, recurrent ischaemic events, and revascularisation

\begin{tabular}{|c|c|c|c|}
\hline & $\begin{array}{c}\% \text { Survival } \\
\text { at } 30 \text { days } \\
\text { (95\% confidence } \\
\text { interval) }\end{array}$ & $\begin{array}{c}\% \text { survival } \\
\text { at } 1 \text { year } \\
\text { (95\% confidence } \\
\text { interval) }\end{array}$ & $\begin{array}{c}\% \text { Survival } \\
\text { at } 3 \text { years } \\
\text { (95\% confidence } \\
\text { interval) }\end{array}$ \\
\hline \multicolumn{4}{|l|}{ Death: } \\
\hline All patients $(n=608)$ & $84.0(80 \cdot 8$ to $86 \cdot 6)$ & $78.3(74.8$ to 81.4$)$ & $70 \cdot 6(66 \cdot 1$ to $74 \cdot 7)$ \\
\hline Thrombolysis $(n=441)$ & $90.4(87.3$ to 92.8$)$ & $84.2(80.3$ to 87.4$)$ & $76.7(71 \cdot 4$ to $81 \cdot 2)$ \\
\hline No thrombolysis $(n=167)$ & $66.7(58.9$ to 73.3$)$ & $62.7(54.8$ to $69 \cdot 6)$ & $54 \cdot 3(45 \cdot 6$ to $62 \cdot 1)$ \\
\hline \multicolumn{4}{|l|}{ Death and recurrent ischaemia: } \\
\hline All patients $(n=606)$ & $80.4(77.0$ to 83.4$)$ & $66.8(62.8$ to 70.5$)$ & $56 \cdot 1(51 \cdot 3$ to $60 \cdot 6)$ \\
\hline Thrombolysis $(\mathrm{n}=440)$ & $86.5(82.9$ to 89.4$)$ & $71 \cdot 7(67 \cdot 1$ to $75 \cdot 8)$ & $60.8(54.9$ to 66.1$)$ \\
\hline No thrombolysis $(n=166)$ & $64 \cdot 1(56 \cdot 2$ to $70 \cdot 9)$ & $54.0(45.9$ to 61.4$)$ & $43 \cdot 2(34 \cdot 8$ to $51 \cdot 4)$ \\
\hline \multicolumn{4}{|c|}{ Death, recurrent ischaemia, and revascularisation: } \\
\hline All patients $(n=604)$ & $75.5(71.9$ to 78.8$)$ & $55.5(51.3$ to 59.4$)$ & $43.3(38.5$ to 48.0$)$ \\
\hline Thrombolysis $(n=439)$ & $80 \cdot 1(76 \cdot 0$ to $83 \cdot 5)$ & $57.9(53.0$ to 62.5$)$ & $44.7(38.7$ to 50.6$)$ \\
\hline No thrombolysis $(n=165)$ & $63.4(55 \cdot 5$ to $70 \cdot 2)$ & $49 \cdot 2(41 \cdot 2$ to $56 \cdot 8)$ & $38.0(29.8$ to 46.1$)$ \\
\hline
\end{tabular}

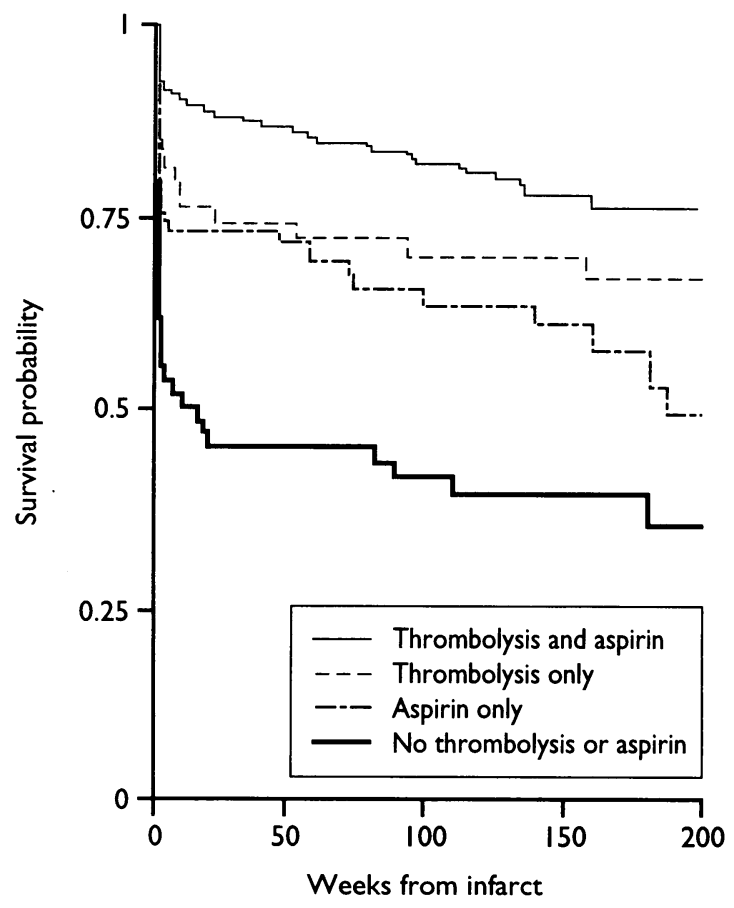

FIG 1-Kaplan-Meier survival curves comparing patients who received thrombolysis therapy and aspirin, thrombolysis only, aspirin only, and neither treatment

Table II shows the clinical characteristics of the 608 patients at baseline. The high proportion of Asian patients reflects the ethnic diversity within the population served by the hospital. Diabetes was present in $36.7 \%$ of Asian patients compared with $14 \cdot 8 \%$ of nonAsians $\left(\chi^{2}=31 \cdot 1 ; \mathrm{p}<0 \cdot 001\right)$.

\section{SURVIVAL ANALYSIS}

Mortality was highest shortly after the infarction, the crude mortality being $9 \cdot 0 \%$ at 48 hours, $12 \cdot 2 \%$ at one week, and $16.0 \%$ at 30 days. After six months the death rate remained about constant $(5 \cdot 3 / 100$ person years) and the estimated mortality was $21.7 \%$ and $29.4 \%$ at one and three years respectively (table III). When all firm events were considered (cardiac death, reinfarction, and readmission with unstable angina) event free survival for the total study population was $80 \cdot 4 \%$ at 30 days, $66 \cdot 8 \%$ at one year, and $56.1 \%$ at three years. Survival in patients treated by thrombolysis was considerably higher than in the rest of the study population. However, the incidence of non-fatal ischaemic events did not differ between patients who did and did not receive thrombolysis $\left(\chi^{2}=0.4 ; p=0 \cdot 5\right)$. Coronary revascularisation was required in $83(14 \%)$ patients, 41 of whom had coronary angioplasty and 42 coronary artery bypass surgery. When need for revascularisation was included in the analysis, the three year event free survival of patients receiving thrombolysis was $44 \cdot 7 \%$.

Most patients received both thrombolysis and aspirin, and the probability of survival was higher for these patients than for those who received either drug alone (table IV, fig 1). Survival was lowest for those patients who received neither thrombolysis nor aspirin $\left(\chi^{2}=56.4, \mathrm{df}=3 ; \mathrm{p}<0.001\right)$.

The presence of left ventricular failure was strongly associated with an adverse prognosis $\left(\chi^{2}=106 \cdot 7, \mathrm{df}=1\right.$; $\mathrm{p}<0.001)$. Thus, 30 day survival was $63.0 \%$ for patients with left ventricular failure compared with $93.7 \%$ for those without (fig 2). Survival of patients with left ventricular failure was $54.0 \%$ at one year and $44.6 \%$ at three years. The presence of $Q$ waves was associated with reduced survival but this did not reach significance $\left(\chi^{2}=3 \cdot 68, \mathrm{df}=1 ; \mathrm{p}=0 \cdot 06\right)$.

Survival was strongly influenced by age and sex 
TABLE IV-Survival probability (all cause mortality) at 1 month, 1 year, and 3 years after myocardial infarction comparing clinical subgroups

\begin{tabular}{|c|c|c|c|}
\hline & $\begin{array}{c}\% \text { Survival } \\
\text { at } 30 \text { days } \\
\text { (95\% confidence } \\
\text { interval })\end{array}$ & $\begin{array}{c}\% \text { survival } \\
\text { at } 1 \text { year } \\
\text { (95\% confidence } \\
\text { interval) }\end{array}$ & $\begin{array}{c}\% \text { Survival } \\
\text { at } 3 \text { years } \\
\text { (95\% confidence } \\
\text { interval) }\end{array}$ \\
\hline \multicolumn{4}{|l|}{ Thrombolysis or aspirin } \\
\hline Thrombolysis only $(n=54)$ & $81.5(68.3$ to 89.6$)$ & $72 \cdot 1(58 \cdot 0$ to $82 \cdot 1)$ & $67.5(52.8$ to 78.5$)$ \\
\hline Aspirin only $(n=103)$ & $74 \cdot 3(64 \cdot 5$ to $81 \cdot 7)$ & $73.1(63.2$ to 80.7$)$ & $62.7(50.8$ to 72.5$)$ \\
\hline Both $(n=387)$ & $91 \cdot 7(88 \cdot 5$ to $94 \cdot 1)$ & $86.0(82.0$ to $89 \cdot 1)$ & $78.2(72.3$ to 82.9$)$ \\
\hline Neither $(n=64)$ & $54.5(41.5$ to 65.7$)$ & $46 \cdot 0(33 \cdot 3$ to $57 \cdot 7)$ & $40.3(27.9$ to 52.3$)$ \\
\hline \multicolumn{4}{|l|}{ Left ventricular failure } \\
\hline No $(n=415)$ & $93.7(90.9$ to $95 \cdot 7)$ & $89 \cdot 6(86 \cdot 1$ to $92 \cdot 2)$ & $82.6(77.5$ to 86.7$)$ \\
\hline Yes $(n=193)$ & $63.0(55.7$ to $69 \cdot 4)$ & $54.0(46.6$ to 60.9$)$ & $44.6(36.3$ to 52.5$)$ \\
\hline \multicolumn{4}{|l|}{ Age (years) } \\
\hline$\leqslant 60(n=284)$ & $92.9(89.3$ to $95 \cdot 4)$ & $87 \cdot 4(82 \cdot 7$ to $90 \cdot 8)$ & $82.7(77 \cdot 0$ to $87 \cdot 2)$ \\
\hline$>60(\mathrm{n}=324)$ & $76 \cdot 1(71.0$ to $80 \cdot 4)$ & $70 \cdot 4(65 \cdot 0$ to $75 \cdot 1)$ & $60 \cdot 2(53 \cdot 5$ to $66 \cdot 2)$ \\
\hline \multicolumn{4}{|l|}{ Sex } \\
\hline Male $(n=447)$ & $87.9(84.4$ to 90.6$)$ & $82 \cdot 1(78 \cdot 2$ to $85 \cdot 5)$ & $74.0(68 \cdot 7$ to $78 \cdot 5)$ \\
\hline Female $(n=161)$ & $73 \cdot 1(65 \cdot 5$ to $79 \cdot 3)$ & $67 \cdot 7(59 \cdot 7$ to $74 \cdot 4)$ & $61 \cdot 3(52 \cdot 5$ to $69 \cdot 0)$ \\
\hline \multicolumn{4}{|l|}{$Q$ wave: } \\
\hline$Q$ wave $(n=472)$ & $81 \cdot 7(77 \cdot 8$ to 84.9$)$ & $76 \cdot 5(72 \cdot 3$ to $80 \cdot 1)$ & $69 \cdot 5(64 \cdot 5$ to $74 \cdot 0)$ \\
\hline Non- $Q$ wave $(n=136)$ & $91.9(85.8$ to 95.4$)$ & $84.7(77.3$ to 89.9$)$ & $74.6(63.9$ to 82.6$)$ \\
\hline \multicolumn{4}{|l|}{ Diabetes: } \\
\hline No $(n=490)$ & $86 \cdot 5(83 \cdot 1$ to $89 \cdot 2)$ & $81.5(77 \cdot 7$ to $84 \cdot 7)$ & $72 \cdot 5(67 \cdot 4$ to $77 \cdot 0)$ \\
\hline Yes $(n=118)$ & $73.5(64.5$ to 80.6$)$ & $65.4(55.9$ to 73.3$)$ & $62.9(53.2$ to 71.2$)$ \\
\hline \multicolumn{4}{|l|}{ Previous myocardial infarction: } \\
\hline No $(n=456)$ & $85 \cdot 7(82 \cdot 1$ to $88 \cdot 6)$ & $80.9(76.9$ to $84 \cdot 2)$ & $72 \cdot 3(68.1$ to $77 \cdot 6)$ \\
\hline Yes $(n=152)$ & $78 \cdot 7(71 \cdot 2$ to $84 \cdot 4)$ & $70 \cdot 5(62 \cdot 3$ to $77 \cdot 3)$ & $62.8(52.8$ to $71 \cdot 2)$ \\
\hline
\end{tabular}
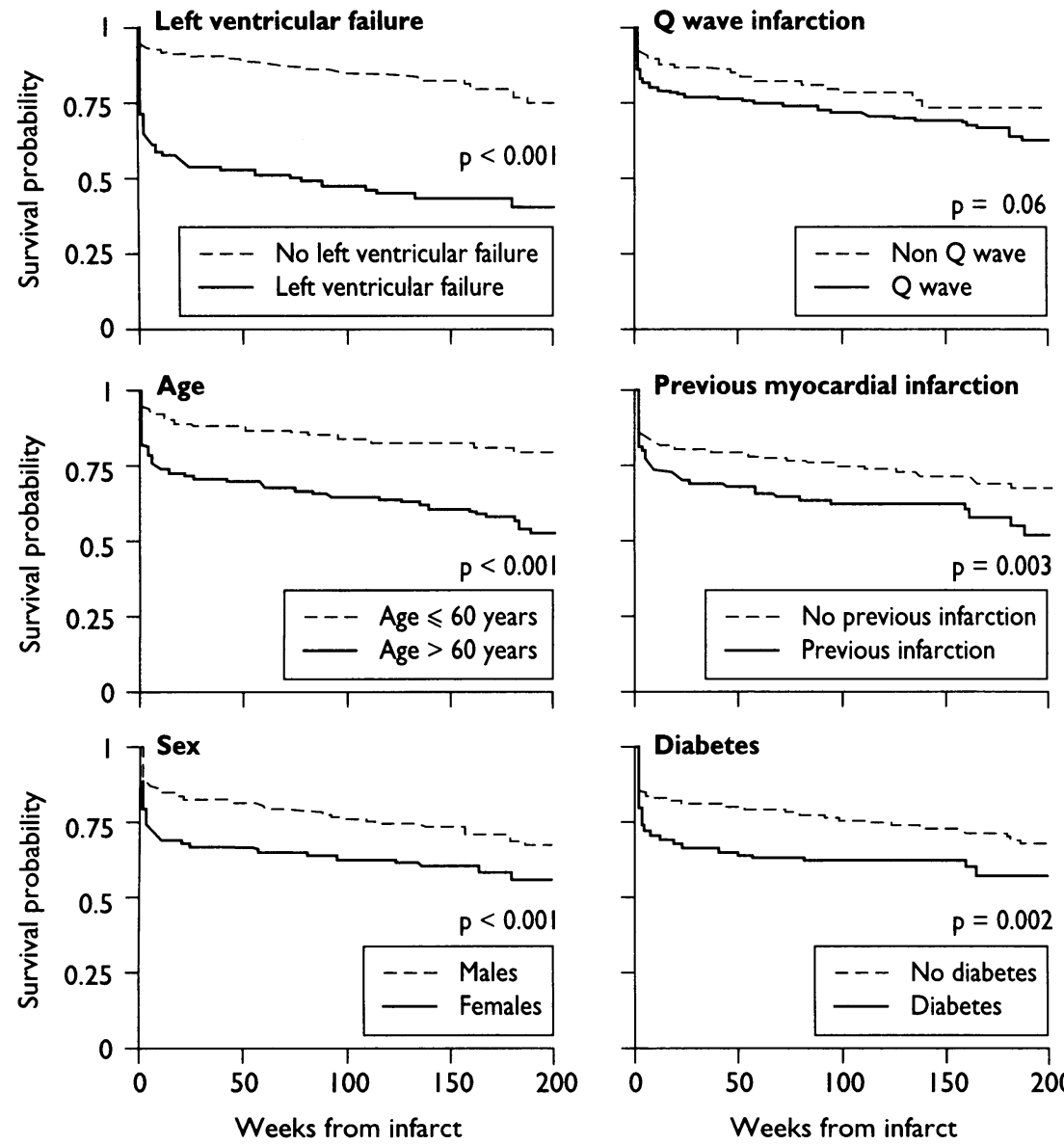

FIG 2-Kaplan-Meier survival curves illustrating the effects on prognosis after infarction of left ventricular failure, $Q$ wave infarction, age, sex, diabetes, and history of myocardial infarction aspirin treatment, and left ventricular failure) were not constant throughout the follow up period. For purposes of multivariate analysis, therefore, survival was partitioned into early ( $<$ six months) and late ( $\geqslant$ six months) periods. Within these periods none of the covariates showed a time dependent effect: log cumulative hazard curves were parallel and there were no significant log time interaction terms (data not tabulated). Table $\mathrm{V}$ lists the clinical variables independently associated with an adverse prognosis. Of these, left ventricular failure was the most important, and was associated with a hazard ratio for early death of 4.36. The rate of death in patients who received thrombolysis was half that in those who did not (hazard ratio 0.57 ) even when left ventricular failure and other covariates were taken into account. Interestingly, when smoking history at the time of admission to hospital was taken into account, non-smokers were at greater risk than current smokers or former smokers.

After the first six months, none of the baseline characteristics predictive of short term survival remained associated with outcome except for age group. Thus, for patients who survived six months, age $>60$ years was the only determinant of an adverse long term (three year) prognosis (hazard ratio $2 \cdot 1,95 \%$ confidence interval $1 \cdot 1$ to $4 \cdot 1$; likelihood ratio $5 \cdot 0$; $\mathrm{p}=0.03$ ).

\section{Discussion}

We have analysed the short and long term prognosis after acute myocardial infarction in a large consecutive series of patients admitted to the coronary care unit of a district hospital. The results show that acute myocardial infarction continues to be associated with a high long term mortality, and although patients treated by thrombolysis had a better prognosis, $39 \%$ had died or had a non-fatal ischaemic event within three years.

A recent meta-analysis of 36 studies conducted before thrombolysis was introduced (1960-87) found that short term prognosis after acute myocardial infarction had improved progressively in the past 30 years, the average in hospital mortality having decreased from $29 \%$ during the 1960 s to $21 \%$ during the 1970 s and to $16 \%$ during the $1980 \mathrm{~s}$; average one month mortality figures during the same three periods were $31 \%, 25 \%$, and $18 \%$ respectively. ${ }^{1}$ The authors suggested that these improvements were likely to reflect parallel improvements in medical care. Thus, although thrombolytic therapy has been shown to produce a clear benefit in randomised clinical trials, ${ }^{5-11}$ these studies have included only selected low risk patients and the impact of thrombolysis on routine clinical practice has yet to be determined.

TABLE V-Multivariate predictors of all cause mortality over the first six months after infarction

\begin{tabular}{|c|c|c|c|c|}
\hline & $\begin{array}{c}\text { Hazard ratio } \\
\text { (95\% confidence } \\
\text { interval) }\end{array}$ & $\begin{array}{l}\text { Likelihood } \\
\text { ratio }\end{array}$ & $\begin{array}{l}\text { Degrees } \\
\text { of } \\
\text { freedom }\end{array}$ & p Value \\
\hline \multicolumn{5}{|c|}{ Left ventricular failure: } \\
\hline No & 1 & & & \\
\hline Yes & $4.36(2.86$ to 6.63$)$ & $52 \cdot 4$ & 1 & $<0.001$ \\
\hline \multicolumn{5}{|l|}{ Thrombolysis: } \\
\hline No & 1 & & & \\
\hline Yes & $0.57(0.38$ to 0.85$)$ & $7 \cdot 60$ & 1 & 0.006 \\
\hline \multicolumn{5}{|l|}{ Aspirin: } \\
\hline No & 1 & & & \\
\hline Yes & $0.43(0.28$ to 0.65$)$ & $15 \cdot 3$ & 1 & $<0.001$ \\
\hline \multicolumn{5}{|l|}{ Smoking: } \\
\hline Non smoker & 1 & & & \\
\hline Former smoker & $0.68(0.41$ to 1.14$)$ & $7 \cdot 57$ & 2 & 0.02 \\
\hline Smoker & $0.57(0.38$ to 0.85$)$ & & & \\
\hline \multicolumn{5}{|c|}{ Bundle branch block: } \\
\hline None & 1 & & & \\
\hline Right & $1.44(0.85$ to 2.43$)$ & $9 \cdot 50$ & 2 & 0.009 \\
\hline Left & $2.85(1.51$ to 5.37$)$ & & & \\
\hline \multicolumn{5}{|l|}{ Age (years): } \\
\hline$\leqslant 60$ & 1 & & & 0.007 \\
\hline$>60$ & $1.78(1.16$ to 2.74$)$ & $7 \cdot 41$ & 1 & \\
\hline
\end{tabular}

(fig 2). In patients aged 60 or less prognosis was usually good with survival figures of $92.9 \%$ and $82.7 \%$ at 30 days and three years respectively compared with $76 \cdot 1 \%$ and $60.2 \%$ in older patients $\left(\chi^{2}=33.3, \mathrm{df}=1 ; \mathrm{p}<0.001\right)$. Survival was also better in men than women, both at 30 days $(87.9 \% v 73 \cdot 1 \%)$ and at three years $(74 \% v 61.3 \%)$ $\left(\chi^{2}=12.3, \mathrm{df}=1 ; \mathrm{p}<0.001\right)$. There was no significant difference in survival between Asian and non-Asian patients $\left(\chi^{2}=1 \cdot 18 ; \mathrm{p}=0 \cdot 3\right)$.

Diabetes $\left(\chi^{2}=9 \cdot 6, \mathrm{df}=1 ; \mathrm{p}=0.002\right)$ and previous myocardial infarction $\left(\chi^{2}=7 \cdot 6, \mathrm{df}=1 ; \mathrm{p}=0.006\right)$ were also associated with reduced survival.

\section{MULTIVARIATE PREDICTORS OF MORTALITY}

Log cumulative hazard plots indicated that hazard ratios for several variables (including thrombolysis, 
The overall 30 day mortality in our study is lower than that reported before thrombolysis was introduced, although it is difficult to draw valid comparisons because of selection factors and differences in base population. Further studies from other centres are needed to confirm that prognosis is continuing to improve. Mortality in the $73 \%$ of patients who received thrombolysis ( $9 \cdot 6 \%$ at 30 days, $15 \cdot 8 \%$ at one year) was close to or within the range of values for the treatment groups $(6 \cdot 0-9 \cdot 4 \%$ at 30 days, $10 \cdot 8-17 \cdot 2 \%$ at one year) reported in randomised trials, even though the patients included in these trials were usually younger. ${ }^{5-11}$

There is relatively little information on long term prognosis, and de Vreede et al were able to identify only 12 reports since $1960 .{ }^{1}$ They found no evidence of time related improvements in long term prognosis, the average five year mortality remaining constant at $33 \%$ in both the 1960s and the 1970s. Direct comparison with our long term follow up is difficult because most of the earliest prognostic data relate to patients surviving to hospital discharge, and there are problems with patient comparability. Nevertheless, the estimated three year mortality rate of $29 \cdot 4 \%$ in our study is not substantially lower than that reported in studies undertaken before thrombolysis was used, and may in part reflect the high incidence of recurrent thrombotic events associated with successful thrombolysis. ${ }^{12-14}$ An additional consideration is the low uptake of $\beta$ blockers, which were given to only $38 \%$ of our patients at hospital discharge. This may reflect the relatively high incidence of contraindications in this east London population (primarily left ventricular failure and chronic lung disease), and had the treatment rate been higher a small improvement in long term outcome might have been achieved. ${ }^{15}$

\section{FACTORS AFFECTING OUTCOME}

Variables identified on subgroup analysis as being associated with outcome were generally the same as those reported before thrombolysis was introduced, the important exceptions being thrombolysis itself and aspirin. Selection for thrombolysis and aspirin was based on clinical indications rather than randomisation, and the more favourable outcome in the treated subgroup cannot be attributed solely to the beneficial effects of these drugs. Nevertheless, it is interesting that our survival curves (aspirin or thrombolysis, or both, versus neither treatment) are similar to those from the second international study of infarct survival. ${ }^{8}$ Left ventricular failure was the most important clinical feature affecting outcome, in accordance with work conducted before thrombolysis was used. ${ }^{16-26}$ The adverse effects of previous myocardial infarction, diabetes, advanced age, and female sex are also well documented. ${ }^{22-24} 27$ The influence of $Q$ wave development on prognosis is less well defined; our data suggest that survival may be lower in this group than in those with non-Q wave infarction. ${ }^{18} 1928$

Multivariate analysis showed that the most important independent determinants of early (six month) mortality were left ventricular failure, not receiving thrombolysis, not receiving aspirin, presence of left bundle branch block at admission, and age greater than 60 . The independent effects of left ventricular failure and advanced age have been well documented. ${ }^{510} 29$ Simoons et al obtained similar results in patients treated with intracoronary streptokinase except that when ejection fraction was taken into account thrombolysis was not a multivariate determinant of survival. ${ }^{30}$ This suggests that its beneficial prognostic effects are partly mediated by preservation of left ventricular function and extend beyond prevention of left ventricular failure. Left bundle branch block usually indicates extensive left ventricular damage and is well recognised as an adverse prognostic finding in

\section{Clinical implications}

- Long term prognosis after acute myocardial infarction in routine clinical practice has not been studied since thrombolysis was introduced

- This study shows that patients treated by thrombolysis have a relatively good prognosis, but long term mortality and incidence of recurrent ischaemic events remains high

- For patients who survived six months, age was the only factor independently related to long term survival

- Effective strategies for identifying and treating high risk patients need to be identified

acute myocardial infarction, although its independent influence has not previously been reported in patients treated by thrombolysis. The adverse effect of these factors occurred relatively early and, with the exception of age group, did not further influence prognosis in those surviving more than six months. Nevertheless, it should be emphasised that other factors known to affect outcome, such as continuing remodelling and dilatation of the left ventricle with increased left ventricular end systolic volume, were not included in our analysis. ${ }^{31}$

The finding that non-smokers were at greater risk of early mortality than current or former smokers was unexpected, but is consistent with the data from thrombolysis in myocardial infarction study II, which showed that non-smokers were at greater risk of reinfarction..$^{29}$ Similarly, in a retrospective analysis of the international tissue plasminogen activator/streptokinase mortality trial smokers had a significantly better hospital and six month outcome than non-smokers or former smokers. ${ }^{32}$ Conversely, Rivers et al found current smoking to be the only factor independently predictive of reinfarction in a much smaller study of 456 patients. ${ }^{33}$ Importantly, the risk of reinfarction was higher in patients who continued to smoke than in those who stopped smoking after the index infarction.

In conclusion, this study has provided important prognostic data for patients with acute myocardial infarction since thrombolysis was introduced. In patients who received thrombolytic therapy, early mortality was similar to that reported in the large randomised trials. Longer term mortality and the incidence of non-fatal recurrent ischaemic events remains high in patients treated by thrombolysis. If long term prognosis is to be improved, effective strategies for the identification and treatment of high risk patients must be developed.

1 de Vreede JJM, Gorgels APM, Verstaaten GMP, Vermeer F, Dassen WRM, Wellens HJJ. Did prognosis after acute myocardial infarction change during the past 30 years? A meta-analysis. $7 \mathrm{Am}$ Coll Cardiol 1991;18:698-706.

2 McGovern PG, Folsom AR, Sprafka M, Burke GL, Doliszny KM, Demirovic $\mathrm{J}$, et al Trends in survival of hospitalised myocardial infarction patients between 1970 and 1985. The Minnesota heart survey. Circulation 1992;85: between $172-9$.

3 Kalbfleisch JD, Prentice RL. The statistical analysis of failure time data. London: John Wiley, 1980;10-9.

4 Cox DR. Regression models and life tables (with discussion). fournal of the Royal Statistical Society [B] 1972;34:187-220.

5 Gruppo Italiano per lo Studio della Steptochi nasi nell'Infarcto Miocardico (GISSI). Long-term effects of intravenous thrombolysis in acute myocardial infarction: final report of the GISSI Study. Lancet 1987;ii:871-4.

6 Wilcox RG, Olsson CG, Skene AM, Von der Lippe G, Jensen G, Hampton JR. Trial of tissue plasminogen activator for mortality reduction in acute myocardial infarction. Anglo-Scandinavian study of early thrombolysis (ASSET). Lancet 1988;ii:525-33.

7 The ISAM Study Group. A prospective trial of intravenous streptokinase in acute myocardial infarction (ISAM): mortality, morbidity, and infarct size at 21 days. N Engl f Med 1986;314:1465-72.

8 ISIS-2 (Second International Study of Infarct Survival) Collaborative Group. Randomised trial of intravenous streptokinase, oral aspirin, both, or neither Randomised trial of intravenous streptokinase, oral aspirin, both, or neither
among 17187 cases of suspected acute myocardial infarction: ISIS-2. Lancet 1968;ii:349-60. 
9 AIMS Trial Study Group. Effect of intravenous APSAC on mortality after acute myocardial infarction: preliminary report of a placebo controlled clinical trial. Lancet 1990;335:545-9.

10 AIMS Trial Study Group. Long-term effects of intravenous anistreplase in acute myocardial infarction: final report of the AIMS study. Lancet 1990;335:427-31

11 Simoons ML, Serruys PW, Brand M, Bars F, De Zwaans C, Res J, et al. Improved survival after early thrombolysis in acute myocardial infarction. Lancet 1985;ii:578-82.

12 Williams DO, Borer J, Braunwauld E, Chesebro JH, Cohen LS, Dalen J, et al. Intravenous recombinant tissue-type plasminogen activator in patients with acute myocardin inforction: a myocardial infarction trial. Circulation 1986;73:338-46.

13 Harrison DG, Ferguson DW, Collins SM, Skorton DJ, Eriksen EE, Kiosho $\mathrm{JM}$, et al. Rethrombosis after reperfusion with streptokinase: importance of JM, et al. Rethrombosis after reperfusion with strepto

14 Ellis SG, Topol EJ, George BS, Kereiakes DJ, Debowey D, Sigmon KN et al. Recurrent ischaemia without warning. Analysis of risk factors for in hospital ischaemic events following successful thrombolysis with intravenous tissue plasminogen activator. Circulation 1989;80:1159-65.

15 Yusuf S, Peto R, Lewis J, Collins R, Sleight P. Beta blockade during and after myocardial infarction: an overview of the randomised trials. Prog Cardiovasc Dis 1985;27:335-71.

16 Wolffenbuttel BHR, Verdouw PD, Scheffer MG, Bom HPA, Bijleveld RE Hugenholtz PG. Significance of haemodynamic variables in coronary care unit for prediction of survival after acute myocardial infarction. $\mathrm{Br}$ Hear $f$ 1983;50:266-72.

17 Deckers JW, Fioretti P, Brower RW, Baarman T, Beelen A, Simoons ML. Prediction of 1 year outcome after complicated and uncomplicated myocardial infarction: Bayesian analysis of predischarge exercise test results in 300 patients. Am Hear f 1987;113:90-8.

18 Krone RJ, Friedman E, Thanavaro S, Miller JP, Kleiger RE, Oliver GC Long term prognosis after first $Q$ wave (transmural) or non- $Q$ wave (nontransmural) myocardial infarction: analysis of 593 patients. $A m \mathcal{F}$ Cardiol 1983;52:234-9.

9 Frabicius-Bjerre N, Munkvad M, Knudsen JB. Subendocardial and transmural myocardial infarction. A five year study. Am $\mathcal{F}$ Med 1979;66:986-93.

20 Murray DP, Salih M, Tan LB, Murray RG, Littler WA. Prognostic stratification of patients after myocardial infarction. Br Heart $\mathcal{f} 1987 ; 57$ : 313-8.

21 Cleempoel H, Vainsel H, Dramaix M, Lenaers A, Contu E, Hoylaerts M, et al. Limitations on the prognostic value of predischarge data after myocardial infarction. Br Heart $\mathcal{f} 1988 ; 60: 98-103$.

22 Henning H, Gilpin EA, Covell W, Swan EA, O'Rourke RA, Ross J. Prognosis after acute myocardial infarction: a multivariate analysis of mortality and survival. Circulation 1979;59:1124-30.

23 Dubois C, Pierard LA, Albert A, Smeets J-P, Demoulin J-C, Boland J, et al. Short term risk stratification at admission based on simple clinical data in acute myocardial infarction. Am $\mathcal{F}$ Cardiol 1988;61:216-9.

24 Sanz G, Castaner A, Betrui A, Magrina J, Roig E, Coll S, et al. Determinants of prognosis in survivors of myocardial infarction. A prospective clinical angiographic study. $N$ Engl f Med 1982;306:1065-70.

25 Norris RM, Barnaby PF, Brandt PWT, Geary GG, Whitlock RML, Wild CJ, et al. Prognosis after recovery from first acute myocardial infarction: determinants of reinfarction and sudden death. Am 7 Cardiol 1984;53. $408-13$.

26 Gomez-Marin O, Folsom AR, Kottke TE, Shu-Chen H, Jacobs DR, Gillum $\mathrm{RF}$, et al. Improvement in long term survival among patients hospitalised with acute myocardial infarction, 1970 to 1980 . The Minnesota Heart Survey. NEngl F Med 1987;316:1353-9.

27 Martin CA, Thompson PL, Armstrong BK, Hobbs MST, de Klerk N. Long term prognosis after recovery from myocardial infarction: a nine year followup of the Perth Coronary Register. Circulation 1983;68:961-9.

28 Pohjola S, Siltanen P, Romo M. Five year survival of 728 patients after myocardial infarction. A community study. Br Hear $\mathcal{F}$ 1980;43:176-83.

29 Mueller HS, Cohen LS, Braunwald E, Formen S, Feit F, Ross A, et al. Predictors of early morbidity and mortality after thrombolytic therapy of acute myocardial infarction. Analysis of patient subgroups in the thrombolysis in myocardial infarction (TIMI) trial, phase II. Circulation 1992;85: 1254-64.

30 Simoons ML, Vos J, Tijssen JGP, Vermeer F, Verheugt FWA, Krauss $H$, et al. Long term benefit of early thrombolytic therapy in patients with acute myocardial infarction: 5 year follow-up of a trial conducted by the Interuniversity Cardiology Institute of the Netherlands. $f \mathrm{Am}$ Coll Cardiol 1989;14:1609-15.

31 White HD, Norris RM, Brown MA, Brandt PWT, Whitlock RML, Wild CJ. End-systolic volume as the major determinant of survival after recovery from myocardial infarction. Circulation 1987;76:44-51.

32 Barbash GI, White HD, Modan M, Van der Werf F. Significance of smoking in patients receiving thrombolytic therapy for acute myocardial infarction Experience gleaned from the international tissue plasminogen activato streptokinase mortality trial. $7 \mathrm{Am}$ Coll Cardiol 1992;20:36-41.

33 Rivers JT, White HD, Cross DB, Williams BF, Norris RM. Reinfarction after thrombolytic therapy for acute myocardial infarction followed by conservative management: incidence and effect of smoking. $7 \mathrm{Am}$ Coll Cardiol 1990;16:340-8.

(Accepted 3 fune 1993)

\title{
National Health Service breast screening programme results for 1991-2
}

\author{
J Chamberlain, S M Moss, A E Kirkpatrick, M Michell, L Johns
}

Cancer Screening

Evaluation Unit, Institute of Cancer Research, Sutton, Surrey SM2 5NG

J Chamberlain,

epidemiologist

S M Moss, statistician

L Johns, higher computer officer

South East Scotland Breast Screening Programme, Ardmillan Terrace, Edinburgh EH11 2JL

A E Kirkpatrick, radiologist

Breast Screening Unit, King's College Hospital, London SE5 9RS

M Michell, radiologist

Correspondence to:

Dr Kirkpatrick.

$B M \mathcal{F} 1993 ; 307: 353-6$

\section{Abstract}

Objectives-To report the results of the NHS breast screening programme for the year March 1991 to April 1992.

Design-A report of statistics was derived from Körner (K62) returns and from the radiology quality assurance programme.

Main outcome measures-Detection rates for breast cancer and small ( $\leqslant 10 \mathrm{~mm}$ diameter) invasive cancer, benign biopsy rates, and recall and acceptance rates.

Results-The acceptance rate for screening across the United Kingdom was $71 \cdot 3 \%$. The referral rate for further investigation was $6 \cdot 2 \%$ (regional $4 \cdot 3-9 \cdot 0 \%$ ). The breast cancer detection rate was $6 \cdot 2$ cancers per 1000 women screened $(5 \cdot 1-9 \cdot 0)$ and the detection rate of invasive cancers $\leqslant 10 \mathrm{~mm}$ was $1 \cdot 4 / 1000$ $(1 \cdot 0-2 \cdot 3) .72 \%$ of screening programmes reached the target $70 \%$ acceptance rate, and $95 \%$ of programmes achieved a recall rate of less than $10 \% .75 \%$ of programmes had a cancer detection rate of more than $5 / 1000$, but only $32 \%$ had a detection rate for invasive cancers $\leqslant 10 \mathrm{~mm}$ of more than $1 \cdot 5 / 1000$.

Conclusions-Overall, the results of the screening programme for the year 1991-2 can be regarded as extremely satisfactory, given the size and complexity of the operation.

\section{Introduction}

After the publication of the Forrest report in $1987^{1}$ a structured breast screening programme for women aged 50 and over was introduced into the National
Health Service. All women aged 50-64 who are registered with general practitioners are invited to be screened by mammography every three years, and asymptomatic women aged over 64 may obtain three yearly screening on demand. By the end of March 1991, 82 separate screening programmes were in operation, and another eight began screening during the next 10 months. These 90 programmes are sufficient to cover the 4.5 million women aged $50-64$ in the United Kingdom once every three years and allow for about $10 \%$ of screening examinations to be self referrals of older women. As each round of screening is planned to extend over three years, only a minority of programmes-those starting in 1988-had completed their first round of invitations by the end of March 1992. The period covered by this report is the year from 1 April 1991 to 31 March 1992, so that all but eight programmes contributed a full year's data; only three contributed less than nine months' information.

\section{Methods}

One aspect of the national quality control of the screening programme is a standardised record system which permits the service to be routinely monitored. A number of different computerised record systems (five in total) have been specifically designed for the NHS breast screening programme, and tables showing various aspects of the performance of the screening service can be produced from these. Each screening programme in England is required to produce a "Körner" statistical return on form $\mathrm{KC} 62$ for the Department of Health each year, and similar arrange- 